\title{
Análise da matriz de competência em uma aplicação real da Avaliação da Aprendizagem em Processo de Língua Portuguesa da Secretaria da Educação do Estado de São Paulo
}

\author{
Daniela Nogueira de Moraes Garcia \\ Universidade Estadual Paulista "Júlio de Mesquita Filho" (UNESP), Assis, São Paulo, Brasil \\ dany7garcia@gmail.com \\ Michelle de Souza Prado \\ Universidade Estadual Paulista "Júlio de Mesquita Filho" (UNESP), Assis, São Paulo, Brasil \\ michelle_prado@hotmail.com
}

DOI: http://dx.doi.org/10.21165/el.v46i2.1689

\begin{abstract}
Resumo
A proposta deste trabalho é discutir a matriz de competência e habilidades da Avaliação da Aprendizagem em Processo $(A A P)$. Esta avaliação é composta por questões objetivas de Língua Portuguesa e é aplicada pela Secretaria da Educação do Estado de São Paulo em escolas públicas de ensino fundamental e médio do estado. O objetivo da prova é medir os coeficientes de aprendizado em língua portuguesa em cada ano escolar. O presente trabalho corresponde a uma análise de caso realizada em uma sala de oitavo ano. O foco da análise está nas questões com maior porcentagem de erro. Tal destaque se dá, pois a AAP utiliza os indicadores em que os alunos apresentam maior fragilidade e que indicam a necessidade de promover ações metodológicas capazes de sanar as lacunas conteudísticas, notadamente, aquelas direcionadas para a competência leitora.
\end{abstract}

Palavras-chave: Avaliação de Aprendizagem em Processo (AAP); matriz de competência e habilidades; competência leitora.

Analysis of the competence matrix in a real application of the São Paulo State Secretary of Education evaluation program of Portuguese language Learning Evaluation as a Process

\footnotetext{
Abstract

This paper aims at discussing the competence and ability matrix of the Learning Evaluation as a Process (LEP). This evaluation is composed by multiple-choice questions of Portuguese language and is applied by the São Paulo State Secretary of Education in the public schools of the state. The goal of the test is to measure the students' levels of Portuguese learning in the middle and high school levels of education in each school year. The present work corresponds to a case study carried out in an eighth grade class. The focus of the analysis is the questions with higher percentage of mistakes. This emphasis occurs because the LEP analyses the indicators in which the students have shown less ability and that indicate the necessity to promote methodological actions in order to fulfill the content needs, especially those focusing on the reading competence. Keywords: Learning Evaluation as a Process (LEP); the competence and ability matrix; reading competence.
} 


\section{Introdução}

As reflexões que se seguem são fruto de uma pesquisa de campo realizada em um $8^{\circ}$ ano da rede pública de ensino do interior paulista. É a análise de um indicador interno ao próprio sistema conhecido como Avaliação da Aprendizagem em Processo (AAP), o qual ocorreu - na época da análise, o ano de 2015 - no início e em meados do ano letivo. A tabulação que analisaremos é do segundo semestre de 2015.

Realizada desde 2011, no ciclo de educação básica nível II e Ensino Médio nas escolas públicas jurisdicionadas à Secretaria da Educação do Estado de São Paulo SEESP, a Avaliação da Aprendizagem em Processo (AAP) é um coeficiente externo à sala de aula, aplicado de cima para baixo, ou seja, do Governo Estadual às unidades escolares, para medir as competências e habilidades que os estudantes alcançaram em detrimento daquilo que eles devem dominar em cada eixo etário e de escolarização, sobretudo em Linguagens e Códigos e Matemática e suas Tecnologias.

Até meados de 2015, o Caderno de Questões consistiu em dez questões objetivas em cada área do saber, citada no parágrafo anterior, e um caderno para desenvolvimento da proposta de algum gênero escrito, propício ao conteúdo de cada ano. A partir do segundo semestre, a produção textual deixou de existir e ao Caderno somou-se 14 questões, perfazendo o total de 24 por "bancada". Todo este esforço tem por fundamento oferecer uma ferramenta diagnóstica ao docente para que possa desenvolver seu plano de ação ao detectar pontos nevrálgicos no que é chamado de eixo das Habilidades e Competências, tópico este que será abordado em destaque, separadamente. Esse "calcanhar de Aquiles" é identificado, primeiramente, pela simples ação de mapear questão a questão o número dos componentes dos dois grupos: aqueles que acertaram a resposta indicada no gabarito e aqueles que não acertaram. Só depois, partimos para uma observação subjetiva de possibilidades do porquê do erro e o que fazer para suplantar a dificuldade.

$\mathrm{O}$ apêndice que acompanha as provas, chamado de "Comentários e Recomendações Pedagógicas”, faz a seguinte exortação sobre as $A A P$ :

Essa ação, fundamentada no Currículo do Estado de São Paulo, tem como objetivo fornecer indicadores qualitativos no processo de aprendizagem do educando, a partir de habilidades prescritas no Currículo. Dialoga com as habilidades contidas no SARESP, SAEB, ENEM e tem se mostrado bem avaliada pelos educadores da rede estadual. Propõe o acompanhamento da aprendizagem das turmas e do aluno de forma individualizada, por meio de um instrumento de caráter diagnóstico. Objetiva apoiar e subsidiar os professores de Língua Portuguesa e de Matemática que atuam nos Anos Finais do Ensino Fundamental e no Ensino Médio da rede Estadual de São Paulo, na elaboração de estratégias para reverter desempenhos insatisfatórios, inclusive em processos de recuperação (SÃO PAULO, 2015, p. 2.)

Nosso artigo abordará o funcionamento da $A A P$, através do seguinte ponto de observação: foram analisadas as 24 questões do segundo semestre de 2015 do Caderno de Questões de Língua Portuguesa, em uma determinada sala de oitavo ano, num município interiorano de São Paulo. Após tabularmos e obtermos os dados físicos de porcentagem de erros e acertos, afunilamos para as questões com maior incidência de erro e, com o auxílio do aparato teórico, lançamos as hipóteses de estratégias que permitam interpretar e compreender o que é exigido. Chamamos de hipóteses, porque acreditamos 
que o aprendizado escolar é difícil de cercear, pois são muitas suas variantes. "Entretanto o docente não pode, devido a isto, se furtar das interações sociais com seus pares e com suas classes, frente ao todo do contexto escolar, com a finalidade de produção de conhecimento por parte do aluno, em especial aquelas baseadas no diálogo" (SOLÉ, 1998, p. 18).

\section{Objetivo}

Estes escritos, além desta introdução explicativa sobre o funcionamento interno da Avaliação da Aprendizagem em Processo e a conclusão, partes necessárias a qualquer trabalho que intenciona discutir de forma científica determinada realidade, seguiremos a seguinte organização: o debate sobre a matriz curricular explicitada nos próprios encartes enviados pela SEESP e o corpus tabulado e analisado da $A A P(2015)$ aplicados a um dado oitavo ano da rede pública.

\section{Matriz de Competências e Habilidades: Contexto de 2015}

Para que possamos apresentar este modelo de avaliação exclusivo do ensino da rede pública paulista, a $A A P$, falaremos, brevemente, dos dois modelos que representaram os dois semestres do ano letivo de 2015: a oitava edição, a qual ainda foi igual a todas as outras edições antecessoras e a nona edição, que apresentou pequenas alterações, como já citado, no número de questões e na perda da produção textual.

Como destacado no excerto anterior, "A Matriz de Referência para $A A P$ ”, utilizada na formulação das questões e que está presente nos Cadernos de Recomendações Pedagógicas, teve como apoio o Currículo do Estado de São Paulo: Linguagens, códigos e suas tecnologias; o Caderno do professor: língua portuguesa; as matrizes do SARESP, da Prova Brasil e do ENEM" (SÃO PAULO, 2015, p. 3). A abordagem da Matriz de Língua Portuguesa será pertinente, neste tópico. A descrição das Competências versus Habilidades de cada enunciado está no fascículo do professor para que o oriente em seu aval pedagógico. Ao lermos esse conteúdo pedagógico que tem a intenção de embasar o trabalho docente, percebemos uma afinação com a concepção de teóricos como Kleiman (2013), Solé (1998) e outros que retomaremos ao longo do artigo. Observe este primeiro excerto teórico:

A leitura e a escrita aparecem como objetivos prioritários da Educação Fundamental. Espera-se que, no final dessa etapa, os alunos possam ler textos adequados para a sua idade de forma autônoma e utilizar os recursos ao seu alcance para referir as dificuldades dessa área - estabelecer inferências, conjeturas; reler o texto; perguntar ao professor ou a outra pessoa mais capacitada, fundamentalmente -; também espera que tenham preferências na leitura e possam exprimir opiniões próprias sobre o que leram (SOLÉ, 1998, p. 34).

Com efeito, ao vislumbrarmos as metas de cada enunciado, percebemos uma predileção natural para situações que envolvam o aluno e seu grau de proficiência textual. Por exemplo, na $A A P-1^{\text {a }}$ edição 2015 do $8^{\circ}$ ano, dos sete eixos descritos, foram avaliados seis, a saber: Eixo I - Procedimentos básicos de Leitura; Eixo II - Implicações do suporte, do gênero, do enunciado e do receptor na compreensão textual; Eixo III - Relação entre textos do mesmo gênero ou de gêneros diferentes; Eixo IV - Coesão e Coerência no 
processamento do texto; Eixo V - Recursos expressivos e efeitos de sentido; Eixo VI Variação Linguística e o Eixo VII - Recursos da Linguagem Literária não é avaliado em todo o nível fundamental, apenas no ciclo médio. As Habilidades são enumeradas do 1 ao 31 e se dividiram entre cada eixo. No caso das 10 questões, foram 10 Habilidades, dispostas entre os 6 eixos. O manual pedagógico se expressa da seguinte forma: Questão $1=$ H3-Eixo1, e assim sucessivamente, basta retornar a cada eixo e ao descritor de cada Habilidade para compreender o que está a ser mobilizado a fim de atingir determinada competência.

Dito de outra forma, as Habilidades (Inferir, Distinguir, Identificar, Reconhecer, Estabelecer e Localizar) repetem-se ao longo de todos os Eixos, e será na intersecção do Eixo "Habilidade" com o Eixo "Temático" (I, II, III, IV, V, VI e VII) que obteremos a Competência, sendo essa aquilo que os compêndios escolares oferecem ao aluno na série em que está matriculado. Deste modo, o aluno pode possuir a Habilidade de Localizar, por exemplo, mas dependendo do Eixo que esta Habilidade está descrita, ele pode ainda não ter atingido a Competência daquele dado Eixo, portanto, a mesma Habilidade é requerida diversas vezes. Mas há Competências distintas a atingir, "em seu conjunto, elas nos fazem ver que, se ensinamos um aluno a ler compreensivamente e a aprender a partir da leitura, estamos fazendo com que ele aprenda a aprender, isto é, com que ele possa aprender de forma autônoma em sua multiplicidade de situações." (SOLÉ, 1998, p. 47).

Por uma decisão didática, abaixo, fizemos uma representação pictórica do esquema mental que descrevemos acima. Trata-se de um gráfico com o Eixo "Habilidades" e o Eixo "Temático". As áreas hachuradas remetem ao encontro dos dois eixos, ou seja, a Competência a ser aprendida.

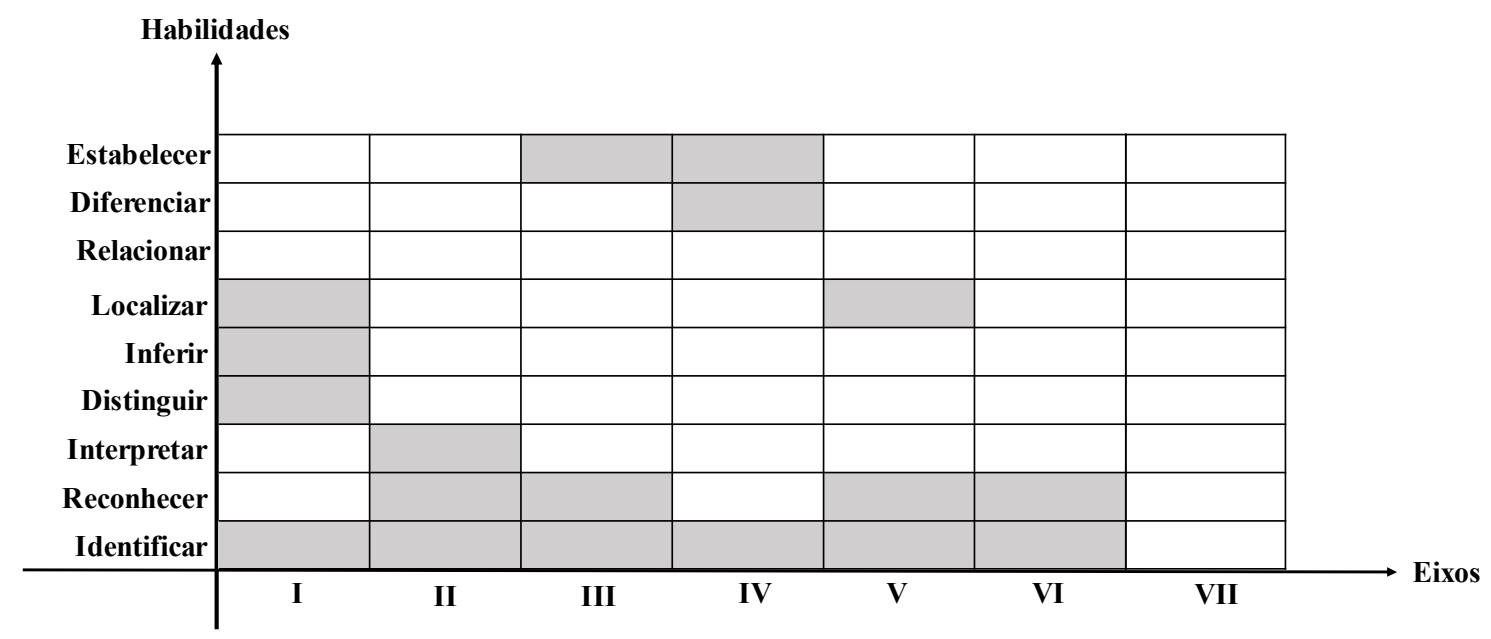

Gráfico 1. Projeção da intersecção do Eixo Competências e Habilidades

Em que pese a observação do eixo VII, sem nenhum destaque, a Competência em Linguagem Literária não é analisada no ciclo II por entender que a Literatura será uma disciplina exclusiva do Ensino Médio. Vale ressaltar que as grelhas de descritores de cada eixo estão na íntegra no Caderno de Comentários e Recomendações Pedagógicas da $A A P$. Ainda sobre a $8^{\mathrm{a}}$ edição aplicada no $1^{\circ}$ semestre, foram constatados $50 \%$ de enunciados no Eixo I, $10 \%$ no Eixo II, $10 \%$ no Eixo IV, $20 \%$ no Eixo V e $10 \%$ no Eixo VI. Ficou evidente a forte inclinação dos indicadores em verificarem o nível de letramento dos 
adolescentes, testando ao longo dos dez enunciados a proficiência leitora dos mesmos em deslindar as armadilhas das questões, baseadas em distintos gêneros.

É característica da proposta curricular do estado de São Paulo o conteúdo ser espiralado, dito de outra forma, repassar o mesmo conhecimento por todos os anos de forma cada vez mais aprofundada, por isso da marcação com um X em mais de uma série para o mesmo descritor. A partir da nona edição, segunda metade de 2015, a Matriz de Referência para Avaliação de Língua Portuguesa passou a se apresentar de uma maneira diferente: as 24 questões foram dispostas de par em par, gerando o total de 12 descritores de habilidades. Contudo, prevalece a meta da $A A P$ de análise reflexiva sobre Habilidades e Competências não atingidas e a busca em elevar o grau de proficiência dos estudantes nas mesmas Habilidades, elencado no Gráfico 1, e Competências de acordo com seu ano escolar. Desta forma, todas as edições, ainda que tenham alterado seu layout, perseguem o mesmo percurso ontológico destacado nesta subseção do texto.

\section{$A A P 2^{\circ}$ semestre de 2015}

Para fins de respeito ao tamanho limite de laudas deste trabalho, optamos em escolher a $A A P 2^{\circ}$ semestre de $2015,9^{a}$ edição, com 24 questões objetivas, para análise dos acertos e distratores escolhidos pelos adolescentes. Tivemos 20 informantes com o desempenho demonstrado nos gráficos seguintes:

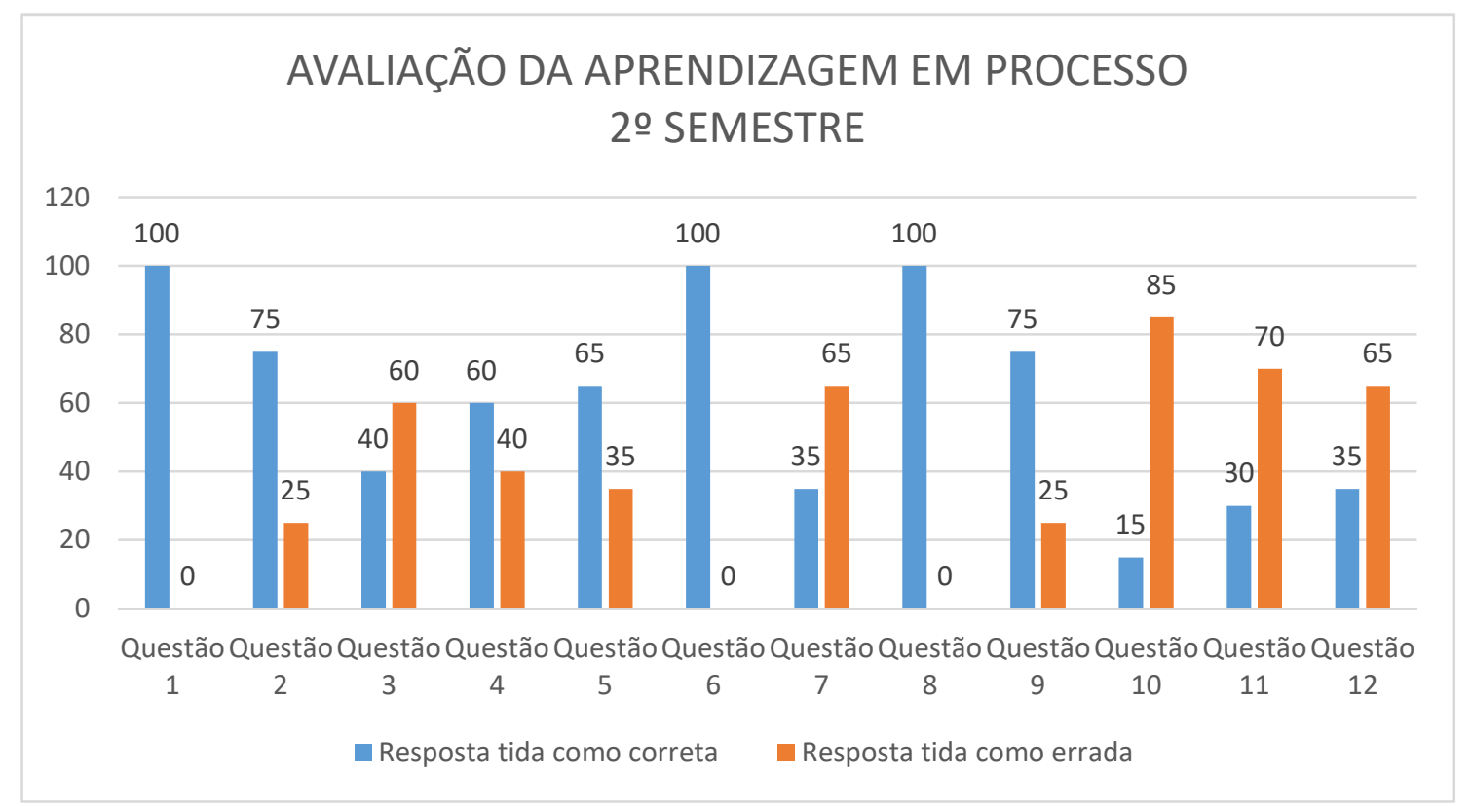

Gráfico 2. Questões de 1 a 12 


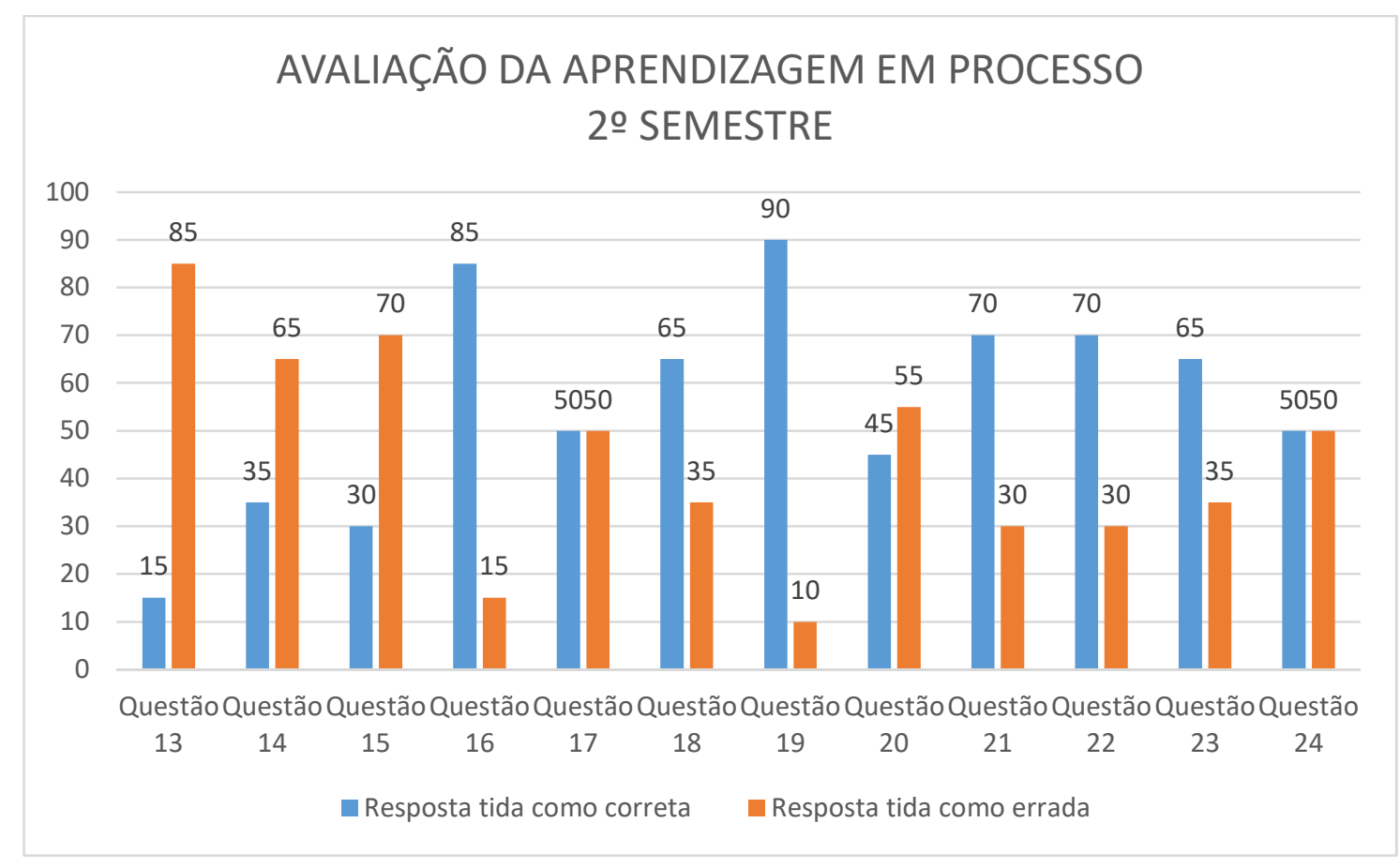

Gráfico 3. Questões de 13 a 24

Essa $A A P$, além de ser mais que o dobro de indicadores do primeiro semestre do mesmo ano, também possui outra diferença essencial, o desempenho dos estudantes. Enquanto no primeiro semestre eles não ficaram abaixo da média em nenhuma das questões, no segundo semestre $37,5 \%$ do total de questões da $A A P$ não foram atingidas, conforme o estipulado pelo próprio sistema avaliativo e passível de visualizar nos dados produzidos e compartilhados acima. Vários são os fatores que podem influenciar na alteração, um deles é por ter se tornado um diagnóstico mais extenso. Como é um caderno com muitos textos a serem lidos, os adolescentes reclamam do tempo que necessitam para resolvê-lo e como o objetivo não é meritocrático, ou seja, não há a conversão para as notas escolares, nem sempre fazem com o mesmo empenho, porque se entediam com tantos gêneros a serem lidos, perguntas e alternativas para decodificar.

Convém relembrar os enunciados que estamos a enfocar, ou seja, aqueles com maior índice de respostas não corretas. Como fica claro no gráfico, trata-se da questão 10 e 13 (ambas com 85\%). Como foi falado, anteriormente, as questões estão de par em par embasadas no mesmo descritor. O caderno pedagógico aponta que o par da questão 10 é a questão 4, e o par da questão 13 é a 15. Retornemos ao gráfico, ainda que seja a mesma Competência/Habilidade, a questão 4 foi atingida por $60 \%$ dos informantes, o que nos faz refletir sobre a direção tomada pelo enunciado, já no outro par, ambas as questões (13 e 15) não foram, na compreensão do esperado pela questão, atingidas pelos informantes, pois a porcentagem abaixo da média expressa que o conteúdo não foi alcançado. Esse outro formato, duas oportunidades discursivas por descritor, nos auxiliará a entender o que pode ter ocorrido, por fornecer mais dados.

Devemos ter em mente ao longo das páginas que se seguem, analisando estes dois pares de questões, o que foi avaliado: as questões 4 e 10 "Identificar a função sintática (sujeito) em textos ou fragmentos de textos (anúncios publicitário e/ou textos 
prescritivos", e as questões 13 e 15, "Reconhecer os elementos constitutivos da organização de um anúncio publicitário" (SÃO PAULO, 2015, p. 5).

Vejamos o exposto sobre Competência e Habilidade em funcionamento, nos textos e questões, logo a seguir. Iniciemos com a questão décima:

\section{Regra para 4 jogadores}

1. Das 12 cartelas-personagens, escolha apenas 8. As demais deverão ser colocadas na tabela de memória com a face virada para baixo, cobrindo os próprios personagens. A tabela de memória ajuda os jogadores a se lembrarem de quais personagens estão participando da partida.

2. Sem que você ou os outros jogadores vejam a figura, retire uma cartelapersonagem entre as 8 escolhidas e a encaixe dentro do livro de "Planos Secletos". Em seguida, coloque o livro no centro do tabuleiro, dentro do muro.

3. Junte a cartela "Turma da Mônica" com as 7 cartelas-personagens e embaralhe-as bem.

4. Distribua 2 cartelas para cada jogador. Ninguém poderá ver as cartelas dos outros jogadores.

5. Distribua também 2 fichas-locais, que devem ser colocadas nos círculos do tabuleiro à frente de cada jogador, com a imagem colorida virada para cima.

6. Cada jogador escolhe um agente Cebolinha e o coloca no tabuleiro em um local com a cor correspondente a uma de suas duas fichas locais.

Retirado do manual de instruções do jogo Agente Cebolinha, da Grow Jogos e Brinquedos S.A.

Figura 1. Imagem do texto da décima questão da $9^{\text {a }}$ edição da $A A P$

É um texto prescritivo, típico gênero curricular estudado no $8^{\circ}$ ano. Três questões fizeram uso destas regras de jogo, a número 9 que questionou sobre ao que se referem os itens elencados no jogo, a número 11, com um desempenho também aquém do esperado, que questiona sobre funções sintáticas do predicado em orações destacadas e a número 10. Vejamos o texto do enunciado com a alternativa considerada correta já negritada:

\section{Questão 10}

$\mathrm{Na}$ oração [...]"A tabela de memória ajuda os jogadores a se lembrarem de quais personagens estão participando da partida" [...], a expressão grifada tem a função de
(A) vocativo.
(B) adjunto adnominal.
(C) adjunto adverbial.
(D) sujeito.

Figura 2. Imagem do gabarito da décima questão da $9^{\text {a }}$ edição da $A \boldsymbol{A P}$ 
Agora, acompanhemos o gráfico da escolha dos alunos entre a resposta e os distratores:

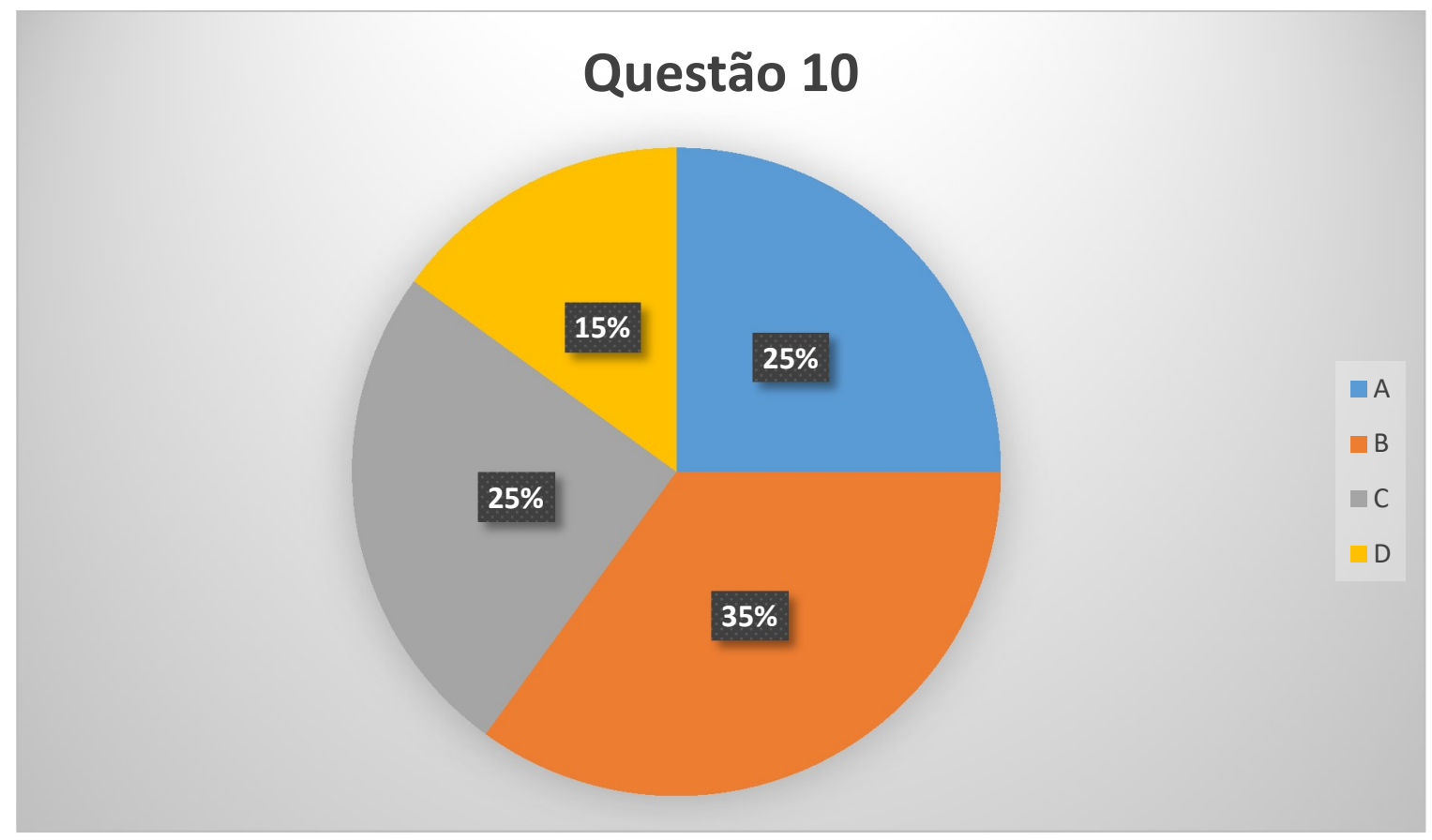

Gráfico 4. Divisão dos informantes pelos descritores - Questão 10

Fator preponderante é que, justamente, a alternativa correta foi alvo do menor número de escolhas. Segundo propostas curriculares oficiais, este conteúdo é realizado no segundo bimestre letivo do $8^{\circ}$ ano. A $A A P$ ocorreu no terceiro bimestre, logo os alunos ainda não haviam conseguido assimilar todo o conceito, como foi possível averiguar através dos dados físicos, a observação e o diálogo em campo. Quando retomamos a outra questão, número 4, que participa da mesma referência de Competências/Habilidades e foi pela maior parte respondida corretamente, temos mais hipóteses do que pode ter havido. Observemos: 


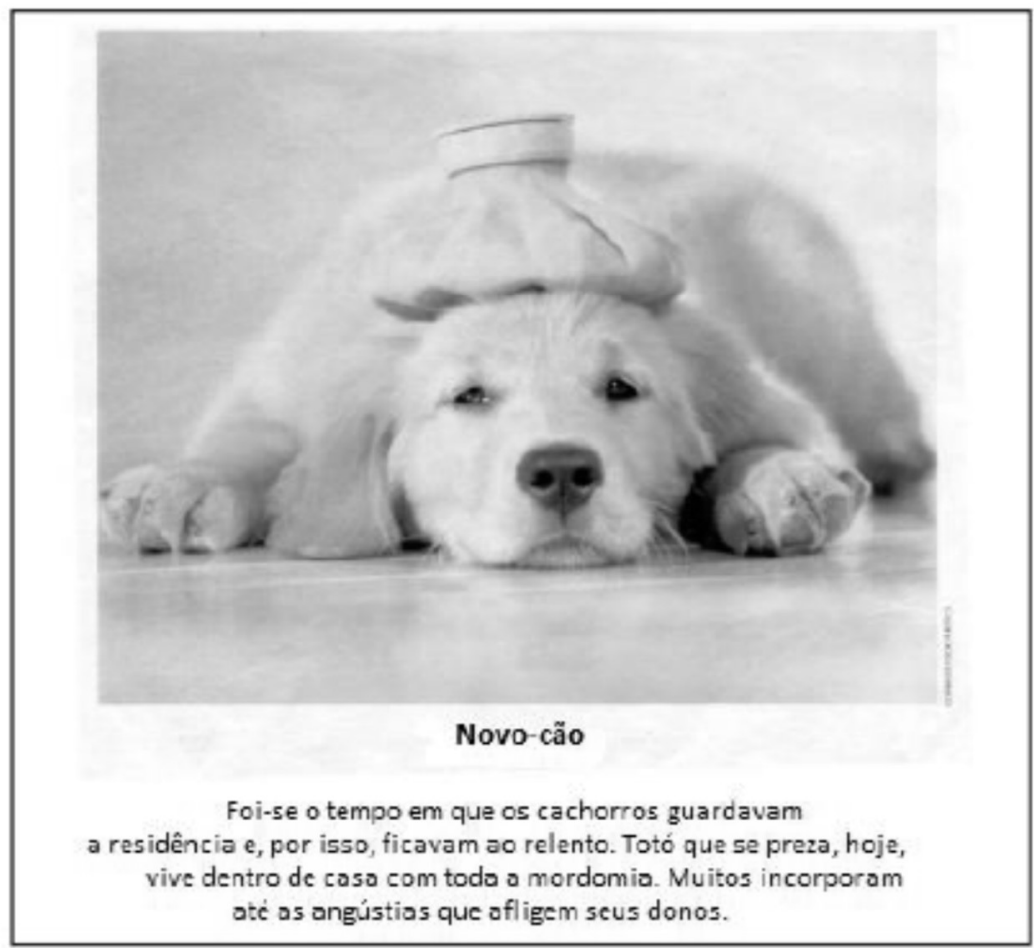

\section{Questão 04}

Na expressão [...] "Totó [...] vive dentro de casa com toda a mordomia" [...] o termo grifado

(A) é um animal, por isso não pode ser o sujeito da oração.

(B) se refere à palavra casa e tem outra função sintática.

(C) não realiza a ação por conta da "mordomia" do cão.

(D) é o sujeito que pratica a ação realizada na oração.

Figura 3. Imagem do texto e do gabarito da questão 04 


\section{QUESTÃO 4}

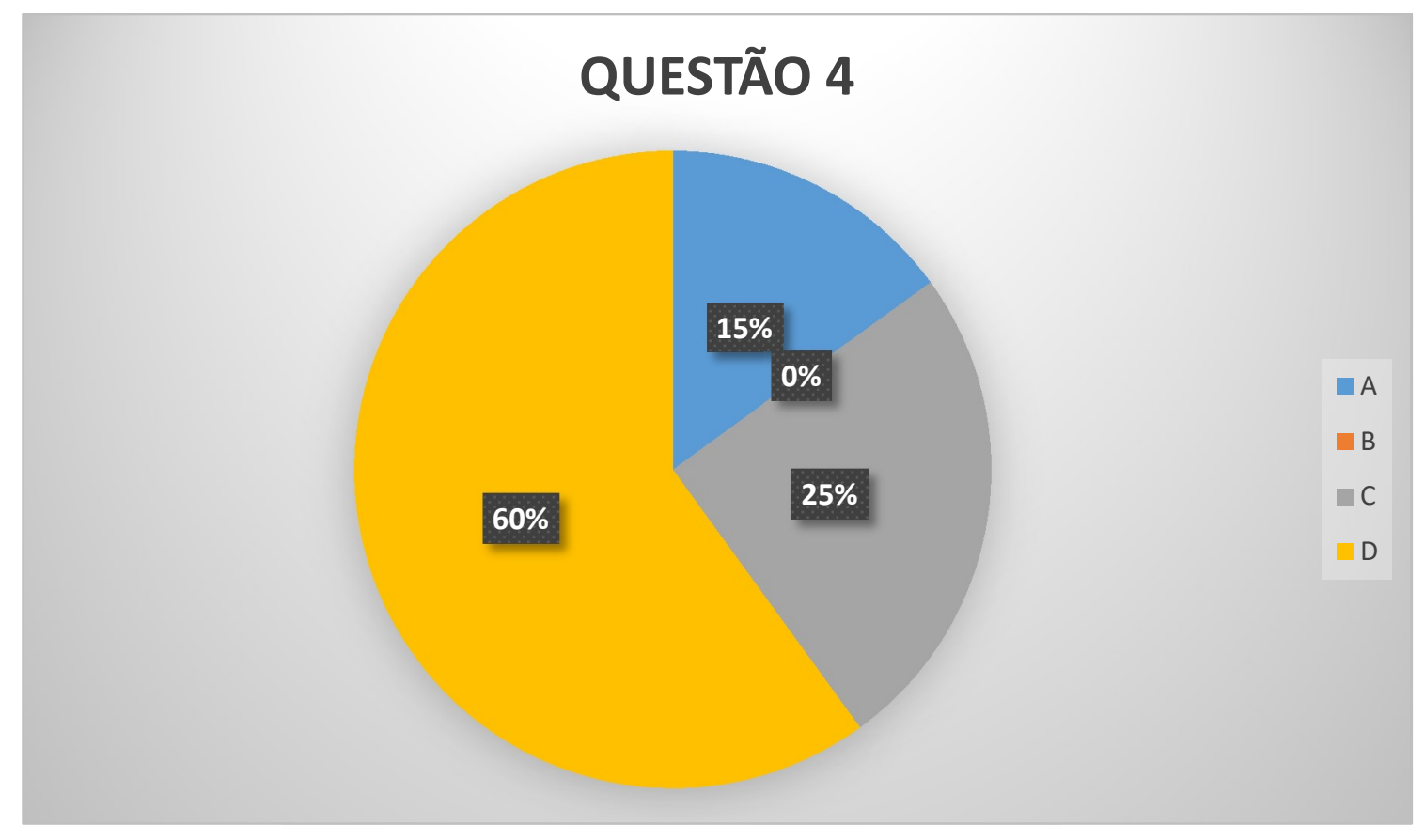

Gráfico 4. Divisão dos informantes pelos descritores - Questão 04

Ora, a sala, em sua maioria, entende qual é a função de um sujeito, aquele que pratica a ação realizada na oração, no caso, o Totó, responsável pelo predicado "vive dentro de casa com toda a mordomia". Curado (2011, p. 27) diz que há "o que se costuma chamar de gramática internalizada, conjunto de regras aprendido e usado na interação comunicativa, desenvolvendo a "competência textual/discursiva", isto é, a capacidade de produzir e interpretar textos". Uma ação existe no universo porque algo ou alguém a fez existir. Contudo, quando se pergunta o mesmo, mas de forma distinta, ou seja, como na questão 10, ao indagar sobre a função sintática de um termo, eles não conseguiram isolar este mesmo sujeito. "Parece-me que é ponto pacífico que a pouca familiaridade com um determinado assunto pode causar incompreensão" (KLEIMAN, 2013, p. 23). A mudança na forma de dispor o questionamento distorceu o grau de proficiência em identificar o sujeito em um texto ou fragmento. Portanto, falar que eles não sabem o que é um sujeito ou que entenderam completamente são extremos desnecessários frente aos resultados das questões 4 e 10 .

Analisemos, agora, o texto da questão 13: 


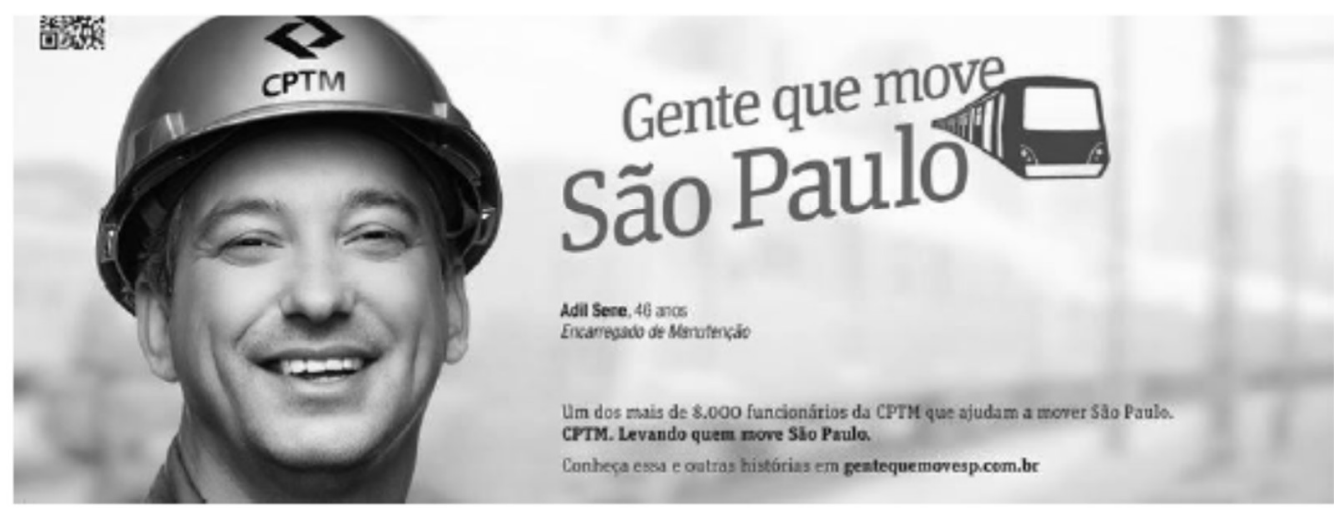

Disponivel em :<http://www.cptm.sp.gov.br/Pages/Home.aspx>. Acesso em: 11 de junho de 2015.

Figura 4. Imagem do texto publicitário da questão 13

Trata-se de um anúncio publicitário, todos seus aspectos são estudados ao longo desta série. Na questão 12, eles não conseguiram definir o público-alvo, razão dos índices em vermelho. No enunciado 13, na íntegra abaixo, nem a informação visual nem a escrita, destacadas na elaboração da questão, encaminharam para uma maior adesão à alternativa aceita como correta (B).

\section{Questão 13}

No anúncio publicitário, o uso da imagem de um funcionário sorridente e os tempos verbais escolhidos tem por objetivo

(A) sugerir ao leitor que utilize mais o transporte público, no caso os trens, que movem São Paulo.

(B) convencer o leitor a acessar uma página na internet para saber mais sobre o assunto.

(C) demonstrar que os funcionários dos trens trabalham sempre dispostos e com aparatos de segurança adequados.

(D) informar aos usuários sobre o número de funcionários que trabalham na manutenção do transporte público.

Figura 5. Imagem do gabarito da questão 04 


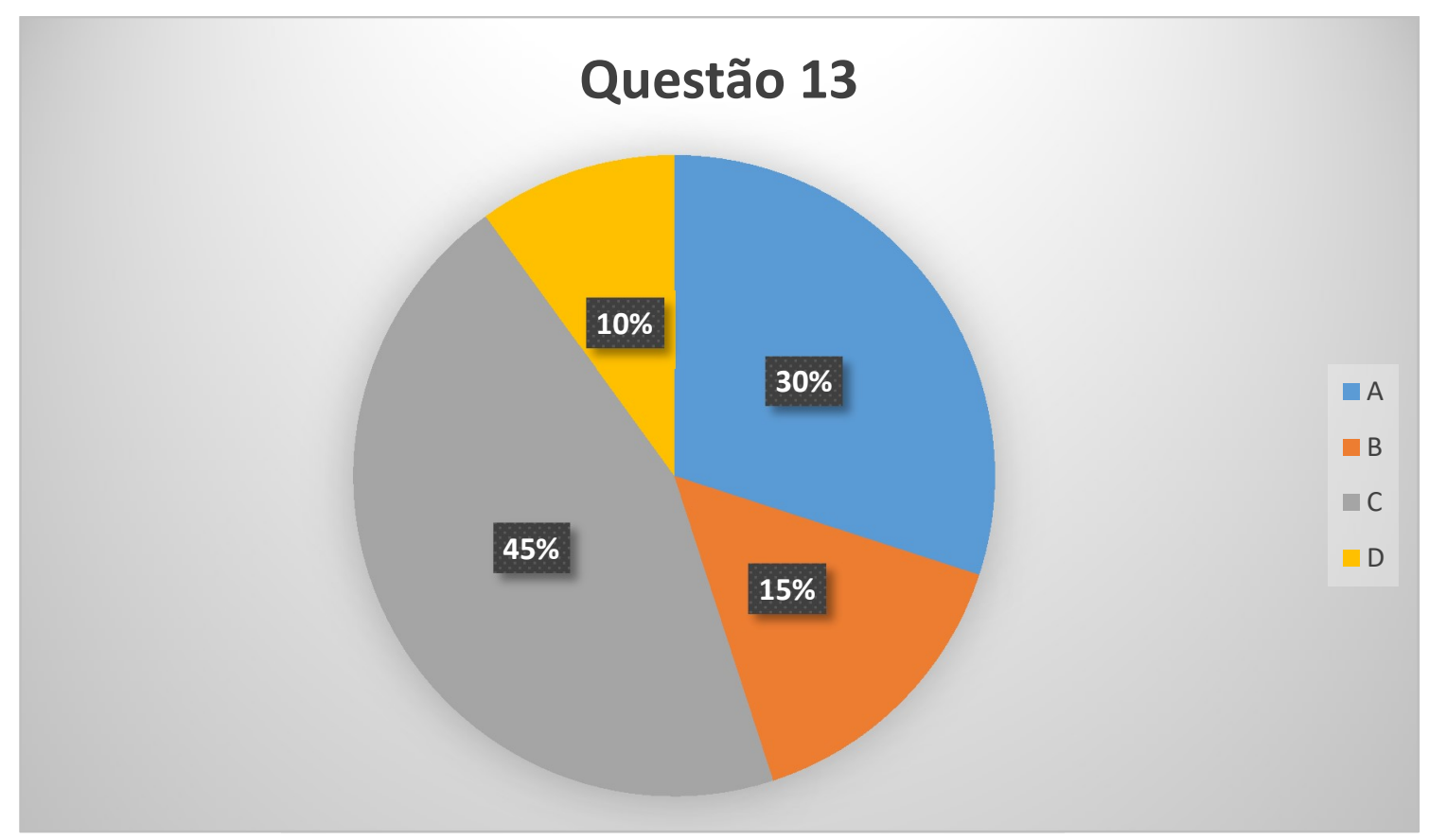

Gráfico 5. Divisão dos informantes pelos descritores - Questão 13

É relevante o distrator C (com 45\%). Os alunos se fiaram apenas na imagem simpática do funcionário, anulando a junção dos tempos verbais ao todo do anúncio, que aparece nas informações escritas em fonte menor ao lado direito da propaganda: "Conheça essas e outras histórias em gentequemovesp.com.br". Desarticular desta forma os elementos presentes na figura é fazer uma leitura superficial, não mergulhar nas inferências de todo o suporte gráfico-textual:

O mero passar de olhos pela linha não é leitura, pois leitura implica uma atividade de procura por parte do leitor, no seu passado, de lembranças e conhecimentos, daqueles que são relevantes para a compreensão de um texto que fornece pistas e sugere caminhos, mas que certamente não explicita tudo o que seria possível explicitar. (KLEIMAN, 2013, p. 30).

Ao contrário do que aconteceu com as questões 4 e 10, os dois indicadores de Habilidade/Competência dos números 13 e 15, "Reconhecer os elementos constitutivos da organização de um anúncio publicitário", estão com resultados desfavoráveis. Antes de prosseguirmos, leremos o enunciado e o gráfico de respostas e distratores da décima quinta: 
Leia o texto e responda às questões 14 e 15.

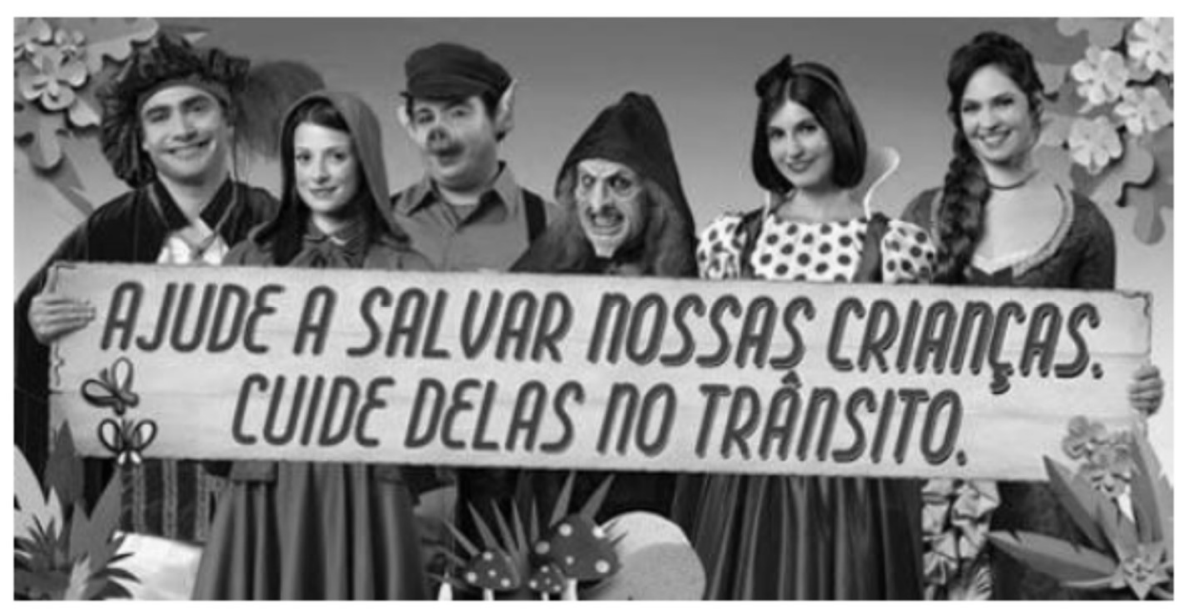

Imagem disponivel em: <http://www.denatran.gov.br/campanhas/hotsite_pelaestradaafora/index.html> Acesso em: 11 de junho de 2015.

\section{Questão 15}

O texto verbal do anúncio publicitário faz um apelo a seu público alvo, que é enfatizado pelo uso de
(A) verbos no modo imperativo.
(B) personagens de contos de fadas.
(C) verbos no modo infinitivo.
(D) personagens de histórias de terror.

Figura 6. Imagem do texto publicitário e o gabarito da questão 15 


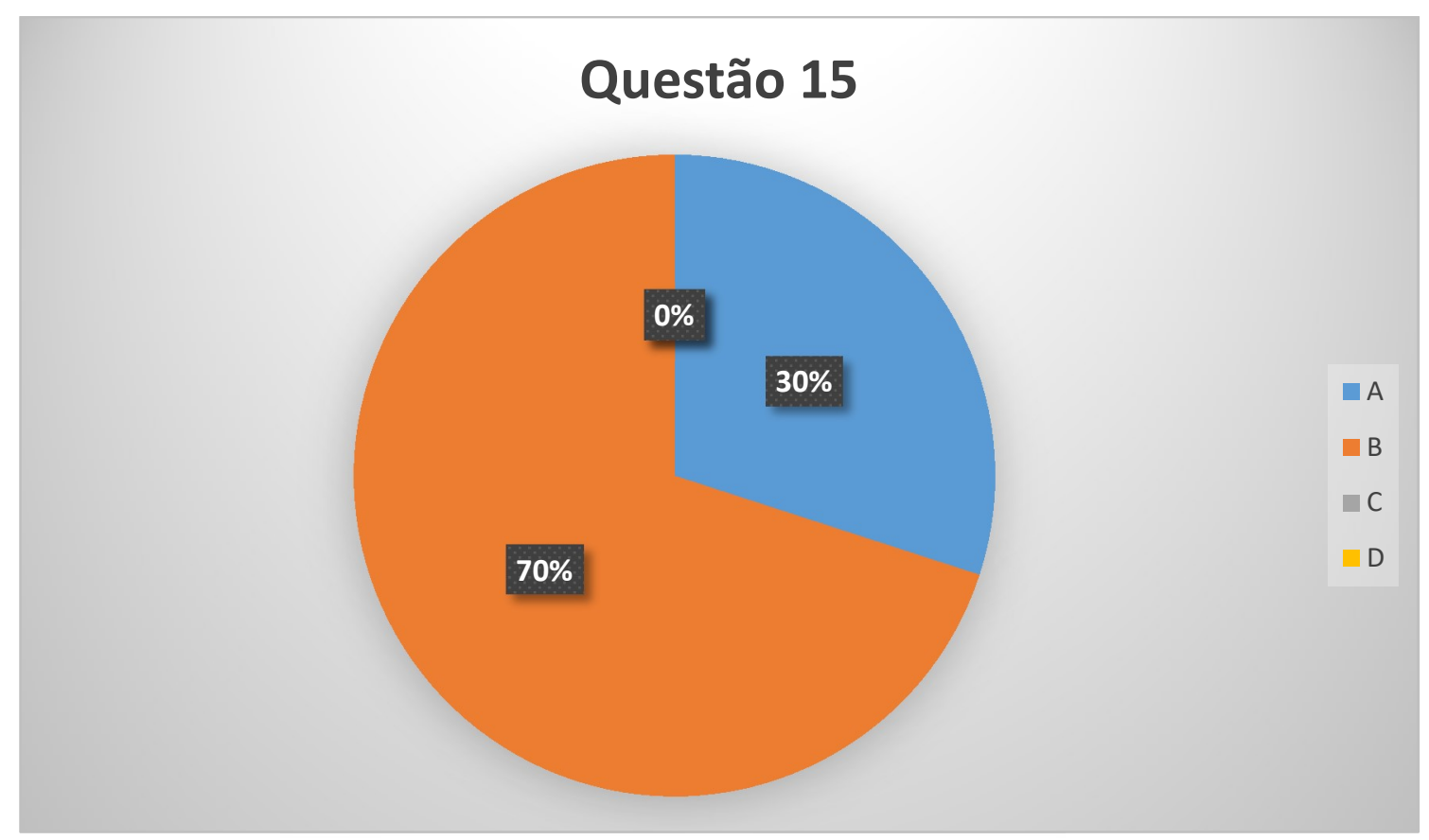

Gráfico 6. Divisão dos informantes pelos descritores - Questão 15

Confirma o que estamos a expor sobre o fato de os alunos verem apenas um continuum, o imagético nos casos, e descartar que se trata de um sobreposto verbal e nãoverbal para compor o todo. Não é à toa que o distrator B ficou com $70 \%$ das escolhas, "personagens de contos de fadas", porque as orações "Ajude a salvar nossas crianças. Cuide delas no trânsito", que são o texto verbal, parece que foram, como na questão 13 , ignoradas. Por outro lado, "o conhecimento de estruturas textuais e de tipos de discurso determinará, em grande medida, suas expectativas em relação aos textos, expectativas estas que exercem um papel considerável na compreensão" (KLEIMAN, 2013, p. 23), os educandos conhecem bem os gêneros contos de fada que os acompanha desde os primeiros anos escolares, portanto, por um automatismo advindo deste conhecimento prévio, logo uniram as figuras do faz-de-conta com a palavra "crianças" e concluíram uma pretensa resposta, o distrator cumpriu bem seu papel ao induzir ao erro mais provável aqueles leitores mais desavisados, por assim dizer. Tanto assim que são dois grupos apenas de informantes, $30 \%$, talvez os leitores mais experientes, que se decidiram pela resposta tida como correta $\mathrm{A}$ e o restante o distrator $\mathrm{B}$, leitores que, porventura, estão um passo anterior ao nível já alcançado de proficiência do restrito outro conjunto.

Válido comentar a questão 14, embora não faça parte do mesmo descritor da $13 \mathrm{e}$ da 15, utilizou o mesmo anúncio aos motoristas acima e questionou sobre o público-alvo. Ao notarmos os resultados do gráfico, nota-se o fato de os adolescentes não identificarem que, apesar dos personagens infantis, o apelo sobre ajudar e cuidar é para os adultos, por ocuparem a posição da direção do carro; daí a importância de se fazer a inferência em todos os aspectos da publicidade disponibilizada. 


\section{Considerações finais}

Para ler necessitamos, simultaneamente, manejar com destreza as habilidades de decodificação e aportar ao texto nossos objetivos, ideias e experiências prévias; precisamos nos envolver em um processo de previsão e inferência contínua, que se apoia na informação proporcionada pelo texto e na nossa própria bagagem, e em um processo que permita encontrar evidência ou rejeitar as previsões e inferências antes mencionadas. (SOLÉ, 1998, p. 23).

Todo ato enunciativo prevê uma vontade, um objetivo a ser atingido. Aí temos a questão da consciência e seu grau de controle do indivíduo. O modo de dizer não é aleatório. $\mathrm{O}$ efeito de saber dizer, entender o como foi dito e o controle das variáveis são o grau de excelência. Muitas vezes, as instituições escolares têm uma preocupação em demasia com que o aluno saiba reconhecer domínios textuais de forma estrutural, mas sonegam a compreensão destas tipologias textuais em contextos reais de uso, bem como as ações da linguagem dentro de cada dimensão tipológica.

Dito de outra forma, com a intenção de afinar com este estudo de caso, o que fica entendido nas edições da $A A P$, sobretudo, com este exemplo demonstrado, é o descarte de dimensões importantes dos enunciados, como a presença do pictórico e, porque usou as inferências e previsões imediatas dos alunos para induzi-los ao erro, ao invés de utilizar caminhos para chegar ao acerto.

A Avaliação de Aprendizagem em Processo é uma ferramenta para diagnosticar o que o professor ensina e como se ensina, antes mesmo de obter o que o aluno aprendeu e como ele aprendeu. Mesmo já contando com nove edições à época, nota-se a necessidade de ajustes quanto ao que se avalia e como se avalia. Encaminhamos ao final este trabalho, deixando as palavras de Solé (1998, p. 33), as quais traduzem, em poucas linhas, como conceber, ainda que sem os ajustes necessários, o atual auxílio que a $A A P$ pode fornecer à equipe pedagógica escolar:

Considero que o problema do ensino da leitura na escola não se situa no nível do método, mas na própria conceitualização do que é a leitura, da forma em que é avaliada pelas equipes de professores, do papel que ocupa no Projeto Curricular da Escola, dos meios que se arbitram para favorecê-la e, naturalmente, das propostas metodológicas que se adotam para ensiná-la. Estas propostas não representam o único nem o primeiro aspecto; considerá-las de forma exclusiva equivaleria, na minha opinião, a começar a construção de uma casa pelo telhado.

\section{REFERÊNCIAS}

CURADO, O. H. F. Linguagem e dialogismo. In: UNESP - Pró-Reitoria de Graduação. (Org.). Caderno de Formação - formação de professores - didática dos conteúdos. v. 3. São Paulo: Cultura Acadêmica, 2011. p. 26-33.

KLEIMAN, A. Texto e Leitor: Aspectos cognitivos da leitura. 15. ed. Campinas: Pontes Editores, 2013. 
SÃO PAULO (Estado). Secretaria da Educação. Coordenadoria de Gestão da Educação Básica. Avaliação da Aprendizagem em Processo. Comentários e recomendações pedagógicas. Subsídios para o Professor de Língua Portuguesa. $8^{\circ}$ ano $/ 1^{\circ}$ semestre. São Paulo: Secretaria de Educação, 2015.

SÃO PAULO (Estado). Secretaria da Educação. Coordenadoria de Gestão da Educação Básica. Avaliação da Aprendizagem em Processo. Comentários e recomendações pedagógicas. Subsídios para o Professor de Língua Portuguesa. $8^{\circ}$ ano $/ 2^{\circ}$ semestre. São Paulo: Secretaria de Educação, 2015.

SOLÉ, I. Estratégias de Leitura. Tradução de Cláudia Schilling. 6. ed. Porto Alegre: ArtMed, 1998.

Recebido em: 31/08/2016

Aprovado em: 23/05/2017 